\title{
Sourcing Red River Jasper: An Archaeological and Geological Investigation of a Gravel Chert in the Red River Drainage
}

Elsbeth L. Dowd

Lyme Art Association

Follow this and additional works at: https://scholarworks.sfasu.edu/ita

Part of the American Material Culture Commons, Archaeological Anthropology Commons, Environmental Studies Commons, Other American Studies Commons, Other Arts and Humanities Commons, Other History of Art, Architecture, and Archaeology Commons, and the United States History Commons

Tell us how this article helped you.

This Article is brought to you for free and open access by the Center for Regional Heritage Research at SFA ScholarWorks. It has been accepted for inclusion in Index of Texas Archaeology: Open Access Gray Literature from the Lone Star State by an authorized editor of SFA ScholarWorks. For more information, please contact cdsscholarworks@sfasu.edu. 
Sourcing Red River Jasper: An Archaeological and Geological Investigation of a Gravel Chert in the Red River Drainage

\section{Creative Commons License}

(c) (i) (8)

This work is licensed under a Creative Commons Attribution-NonCommercial 4.0 International License 


\title{
SOURCING RED RIVER JASPER: An ArchaEological AND GEOLOGiCAl InVESTIGATION OF A GRAVEL CHERT IN THE RED River DRAinAGE
}

\author{
Elsbeth Linn Dowd
}

\begin{abstract}
Red River Jasper, a lithic material found in the Red River drainage, is an understudied chert that was widely used by prehistoric populations in this region from the Archaic to late prehistoric (Caddo) periods. Despite its common occurrence at sites along the Red River, this tabular chert has received little attention compared to other raw materials on the eastern margin of the Southern Plains. Although the material is macroscopically diverse, ranging in color from brown to yellow to red, microscopic analysis indicates that the material is relatively homogeneous and likely came from a limited set of sources. The archaeological distribution of Red River Jasper, geological evidence, and a stream survey of gravels demonstrate that the primary bedrock source was located in the Johns Valley Formation of the Ouachita Mountains and was carried downstream by the Kiamichi River into the Red River.
\end{abstract}

\section{Introduction}

Archaeologists have long recognized that a lithic material known as Red River Jasper was widely used by populations living along the Red River drainage in Oklahoma, Arkansas, Texas, and Louisiana. Various people manufactured lithic tools from Red River Jasper as early as San Patrice times (10,400 to 9,000 B.P.) (Jennings 2006) through the late prehistoric period (Figure 1). This tan to reddish brown chert occurs naturally as tabular pebbles in the gravels of the river. Archaeologists have commonly characterized this material as a local chert that was acquired opportunistically from gravel bars along the Red River. The material is more widespread archaeologically, though, occurring frequently at sites along the Little and Kiamichi Rivers that drain the Ouachita Mountains in Oklahoma. This paper examines the character and distribution of Red River Jasper in order to understand where it originates and how its natural range corresponds to its archaeological distribution. Although the archaeological implications regarding the origins of stream-deposited gravel are less profound than those for a quarried material, defining the natural range of any lithic material allows archaeologists to address the processes surrounding procurement, mobility, and trade, which are essential for understanding the technological, social, and cultural practices of prehistoric groups.

This paper begins with a description of the material and the parameters of its variation, both macroscopic and microscopic. Despite variability in color, a microscopic examination of structure and mineralogy through electron microprobe analysis indicates that Red River Jasper is a relatively homogenous material that may have come from a restricted set of sources. Next, the archaeological and natural distributions of the material are examined through artifact analysis and a survey of stream gravels along the Kiamichi River (Figure 2). Based on those distributions, several localities that cross-cut the John's Valley formation in the Ouachita Mountains are identified as potential sources for Red River Jasper. 


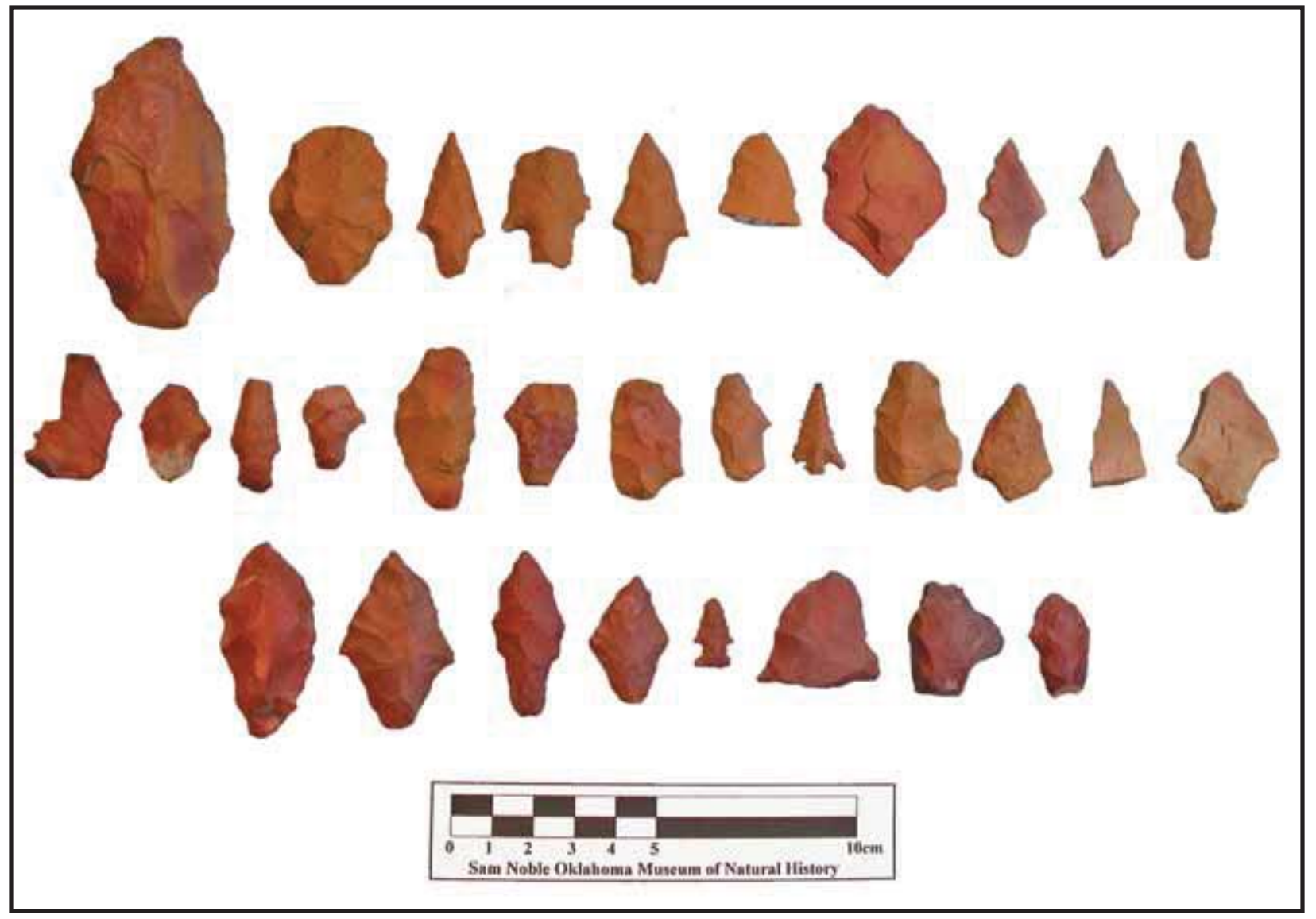

Figure 1. Red River Jasper artifacts from the A.W. Davis site (34MC6) in McCurtain County, Oklahoma.

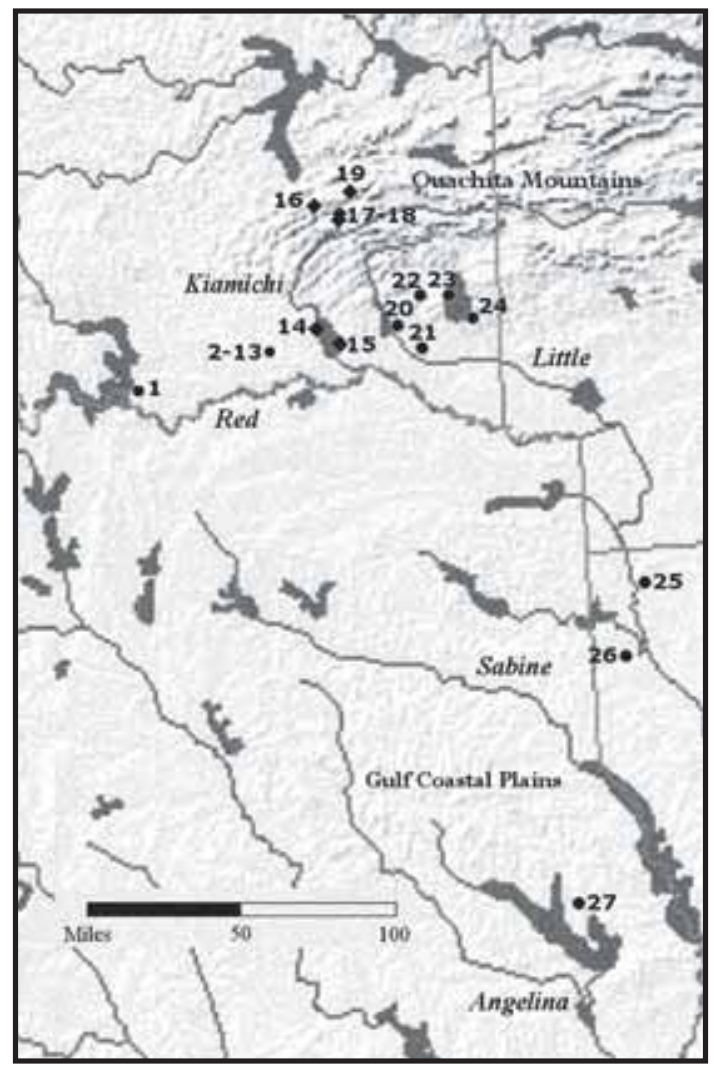

Figure 2. Sites and localities discussed in paper.

(1) James site, 34BR11;

(2-13) 34AT105 - 34AT117;

(14) Montgomery site, 34CH70;

(15) Mahaffey site, 34CH1;

(16) Natural Lake site, 34PU71;

(17) Blessingame site, 34PU74;

(18) Arrowhead Hill site, 34PU105;

(19) Buffalo Bend site, 34PU111;

(20) Bell site, 34MC76;

(21) A.W. Davis site, 34MC6;

(22) Pine Creek Mound Group site, 34MC146;

(23) Bill Hughes site, 34MC21;

(24) Biggham Creek site, 34MC105;

(25) Willow Chute Bayou locality, Bossier Parish, LA;

(26) John Pearce site, 16CD56;

(27) Wolfshead site, 41SA117. 


\section{Material Analysis: Macroscopic Variation, Microscopic Homogeneity}

\section{Macroscopic Description}

While Red River Jasper is easily recognizable in its classic form, it encompasses a relatively large amount of macroscopic variation, particularly in color (Figure 3). As defined by Leudtke (1992:151), jasper is "a variety of chert containing iron oxide impurities that generally result in a characteristic gold, brown, or red color." The Glossary of Geology published by the American Geological Institute concords with that definition, but adds that while jasper is "characteristically red ... yellow, green, grayish-blue, brown, and black cherts have also been called jasper" (Bates and Jackson 1980:2). Most commonly the cortex of Red River Jasper can be described as brown to strong brown (7.5YR5/4 to 7.5YR5/6), but it also occurs in other shades including light brown (7.5YR6/4), yellowish brown (10YR5/4), reddish yellow (7.5YR6/8), weak red (10R4/3), dusky red (10R3/3), and pink (7.5YR8/4). Likewise, the interior is most regularly brown to strong brown, but also occurs in the above-mentioned shades. The interior frequently displays a combination of these colors, with a banded, mottled, or transitional structure. Often the material grades from yellowish brown in the middle to red near the cortex, although in some instances the opposite pattern occurs. In certain cases, particularly in the upper reaches of the Kiamichi, the interior includes shades of gray and light olive brown (2.5YR5/3). Here, these darker shades usually are located in the interior of the material and grade to red or yellowish brown near the cortex. These patterns will be discussed later in relation to the formation of this material and subsequent chemical weathering.

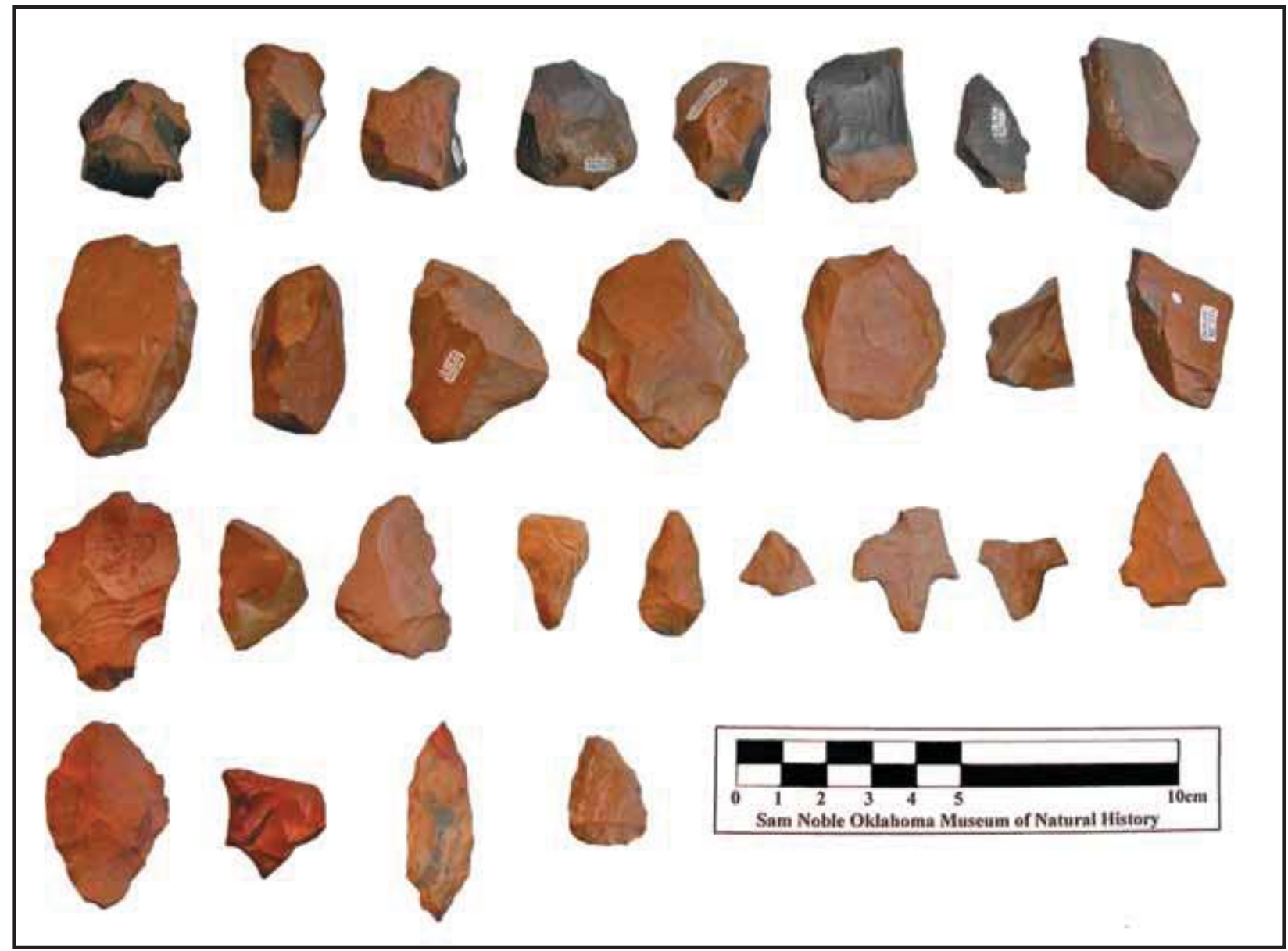

Figure 3. Transitional zones of gray and yellowish brown present within Red River Jasper artifacts from the Arrowhead Hill site (34PU105) along the upper Kiamichi River, Pushmataha County, Oklahoma. 
All Red River Jasper has a smooth water-worn cortex, evidence of alluvial transport (Figure 4). The interior has a fine texture. The material is generally dull, but some fine-grained pieces are lustrous. It is not translucent. It commonly contains mineral inclusions that appear as white or dark brown specks.

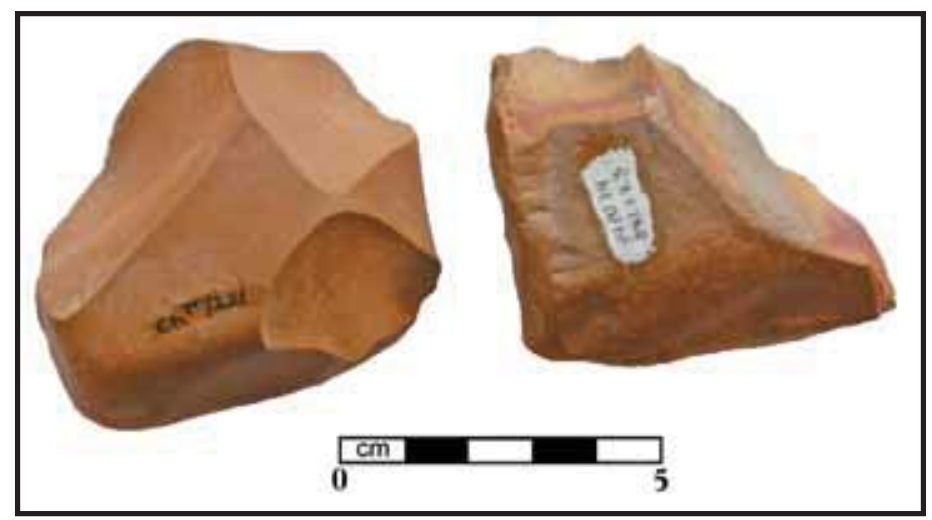

Figure 4. Two Red River Jasper cores, illustrating stream-rolled cortex, from sites 34CH70 and 34 PU74 respectively in Choctaw and Pushmataha counties, Oklahoma.

The average dimensions of Red River Jasper gravels can be estimated from the measurement of cores, which are artifacts that have had flakes removed but are at a very early stage in the reduction sequence. Measurements of maximum length and maximum thickness for Red River Jasper cores were taken from a sample of 77 cores from seven sites along the Kiamichi and Little River drainages (Table 1). Measurements of maximum length form a normal distribution, with a mean of $5.64 \mathrm{~cm}$, whereas measurements of maximum thickness are positively skewed, with a mean of $1.97 \mathrm{~cm}$ (Figures 3 and 4). The positive skew indicates that most cores are relatively thin. Overall, these dimensions demonstrate the small size of the initial gravels that the knappers had to work with. This should be kept in mind when considering the final size and degree of cortex on the finished tools.

The shape of these cores was determined by dividing the maximum length of each core by its maximum thickness. This ratio indicates whether a core is more round (closer to a 1:1 ratio) or more tabular (greater than a 1:1 ratio). The distribution of the ratios for this sample of cores is positively skewed, with a mean of 3.13 $\mathrm{cm}$ (Figure 5). The positive skew indicates that most of the cores are relatively tabular and that some are very tabular. Using small, tabular cobbles, a knapper most likely would have reduced the cobble directly to make a tool, rather than working a flake blank. This size and proportion also explain why a number of tools made from this material retain some cortex (Figure 6 and Table 2).

Table 1. Dimensions of Red River Jasper cores $(n=77)$ from study sites.

\begin{tabular}{|l|l|c|c|}
\hline Measurement & Range $(\mathbf{c m})$ & Mean $(\mathbf{c m})$ & Standard Deviation \\
\hline Maximum Length & $2.69-8.71$ & 5.64 & 1.22 \\
\hline Maximum Thickness & $0.82-4.31$ & 1.97 & 0.66 \\
\hline Length:Thickness & $1.22-6.62$ & 3.13 & 1.14 \\
\hline
\end{tabular}

Table 2. Number and percent of artifacts with cortex, grouped by reduction stage, from all Red River Jasper assemblages.

\begin{tabular}{|l|c|c|c|}
\hline Reduction Stage & n Total & n with Cortex & \% with Cortex \\
\hline Core & 77 & 77 & 100 \\
\hline Early Stage Biface & 18 & 18 & 100 \\
\hline Late Stage Biface & 44 & 18 & 41 \\
\hline Preform & 41 & 12 & 29 \\
\hline Finished Tool & 90 & 9 & 10 \\
\hline
\end{tabular}




\section{Shape of Red River Jasper Cores}

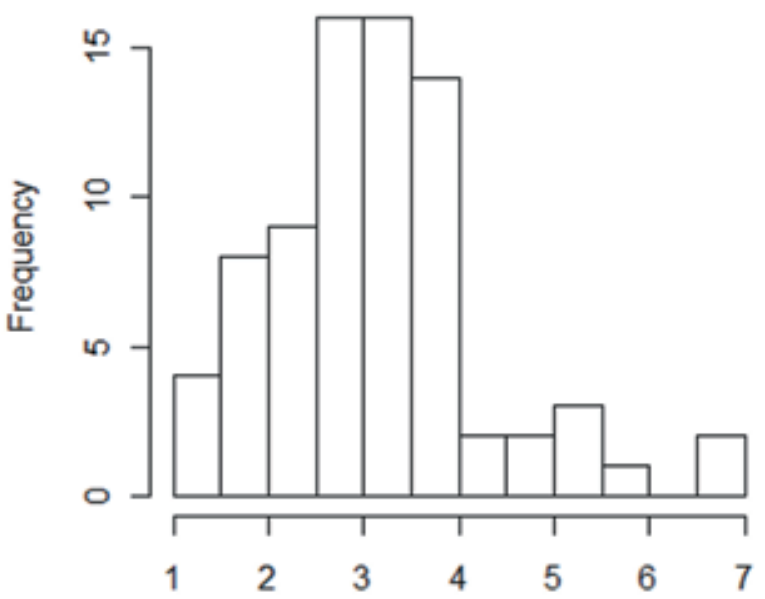

Length to Thickness: Higher Ratio = More Tabular

Figure 5. Shape of Red River Jasper cores $(n=77)$ from study sites, based on ratio of maximum length to maximum thickness. The higher the ratio, the more tabular the core (and likely the more tabular the original cobble). Most of these cores are tabular; they are at least 2-4 times longer than they are thick.

\section{Percent of Artifacts with Cortex within each Reduction Stage}

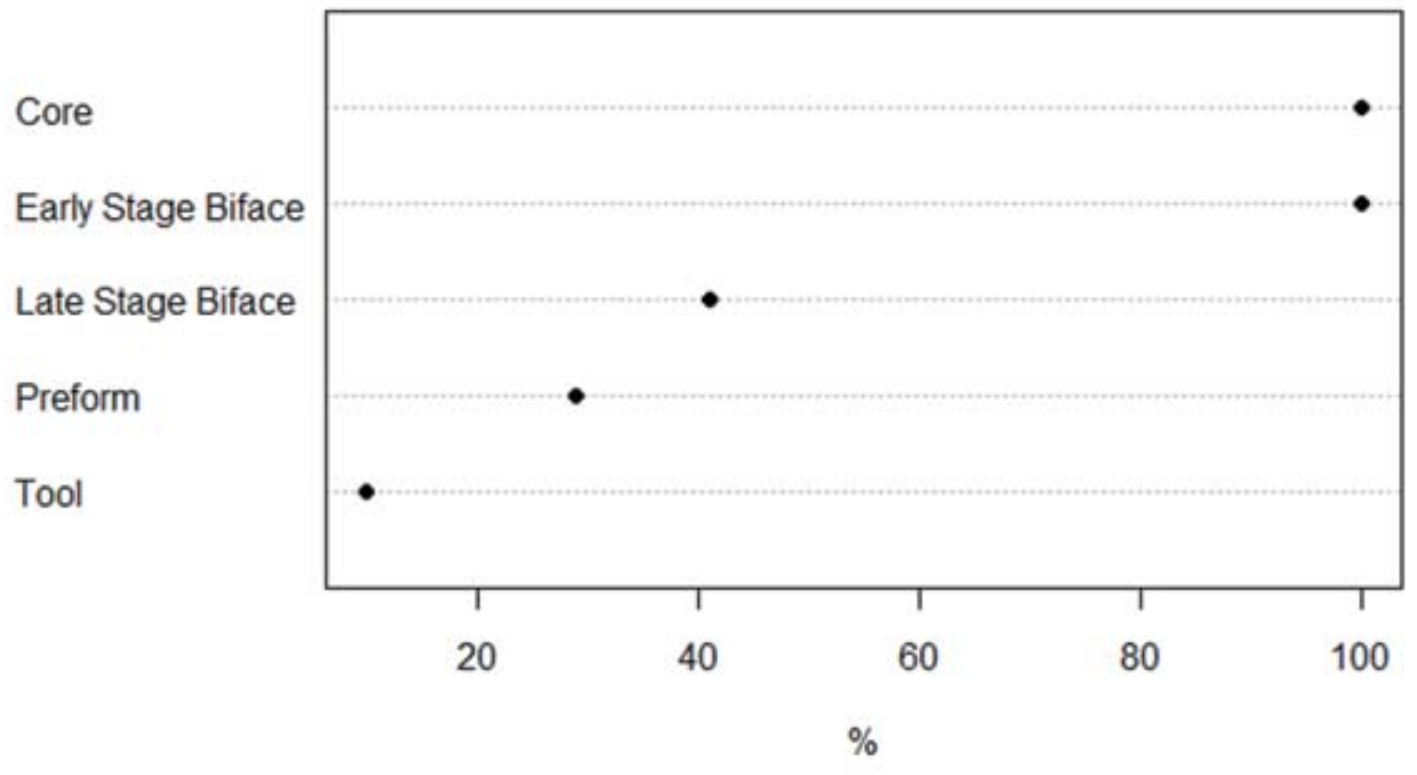

Figure 6. Within each assemblage of Red River Jasper, artifacts were classified by reduction stage as debitage, cores, early stage bifaces, late stage bifaces, performs, or tools. This graph shows the total percentage of artifacts with cortex within each reduction stage. As expected, flint-knappers removed more cortex as they reduced the material. A number of finished tools, however, still have cortex on them, because it was sometimes difficult to remove all cortex from the small tabular cores. The size and shape of the cores also helps explain the red tips and ears on some points. 
The small size and tabular shape of the cobbles additionally accounts for a particular pattern of color variation exhibited by a number of projectile points. As noted by Jennings (2006:13), some San Patrice points that are mainly yellowish brown have red tips and ears. These include points from the John Pearce site (Webb et al. 1971). Later points from sites along the Kiamichi and Little River drainages also display this pattern (Figure 7). Jennings questioned whether this reddening was a result of heat treatment (either associated with hafting or prior to knapping) or whether it was due to the natural composition of the gravel. The appearance, size, and shape of the cobbles in this study suggest that these red tips and ears on points were directly related to the natural condition of the Red River Jasper gravels.

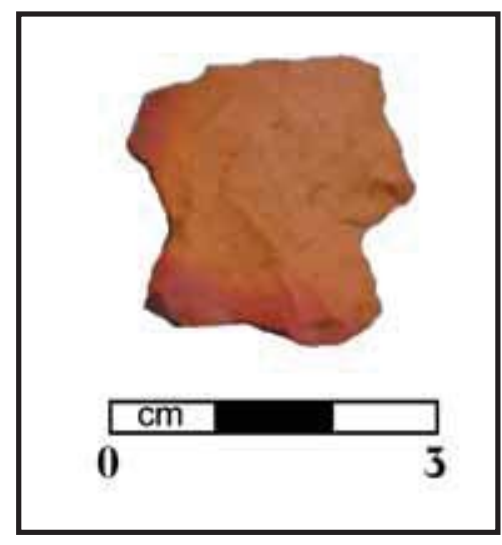

Figure 7. Broken point from the Blessingame site (34PU74) illustrating red color at the edges of the point.

\section{Microscopic Structure}

Macroscopic variation in Red River Jasper falls mainly in the realm of color, which grades from red to yellowish brown to gray. These color differences most likely exist because of differences in the type and concentration of various iron oxides within the material. The concentration of iron oxides in jasper is often attributed to its formation in hydrothermal fluid, which is groundwater that has been heated by magma or metamorphism (Lovering 1972; Luedtke 1992:45-46, 51). In such cases, the hydrothermal fluid flows through the forming chert, carrying dissolved chemicals that contribute to the formation process. It is also possible, however, for chert to undergo post-diagenic (post-formation) chemical weathering, particularly in a warm and humid climate, which could involve the process of oxidation (Hurst and Kelly 1961:253; Luedtke 1992:44,108). Because chert is somewhat porous, water can seep slowly through it, enabling oxidation and other chemical and physical weathering processes to occur. Iron compounds in a chert might slowly undergo oxidation, weathering chemically into iron oxides that would give the chert a red to yellowish brown color. This process would form a weathered rind, or a zone of chemical alternation extending from the exterior towards the interior of the chert nodule (Gordon and Dorn 2004:853).

This process of post-diagenic chemical weathering is the most likely explanation for the color variation present in Red River Jasper, given the distribution of that variation from the cortex to the interior of the cores. When chert nodules from the primary (bedrock) context-which was likely originally gray and contained iron compounds-eroded into a stream, they began to undergo chemical weathering. Although the timing of chemical weathering is complicated (Luedtke 1992:107), it is probable that the longer the chert was exposed to water, the more weathering occurred. As the nodule traveled downstream, it generally weathered more red or yellowish brown and less gray, starting first with the cortex and moving progressively into the interior. This process would not occur uniformly in all chert nodules from the parent formation, given the chemical variability that exists throughout most formations and even within small sections of nodules (Luedtke 1992:57-59). The process of oxidation through chemical weathering fits well with the distributional evidence for the source of this material, as discussed later in this paper. 
In order to further understand the structure and composition of Red River Jasper, particularly the zones of color transition, six samples were selected for microscopic examination using electron microprobe analysis (EMPA). EMPA, which is similar to scanning electron microscopy (SEM), is most useful for examining the structure and mineralogy of solid materials. Samples were selected to encompass a range of macroscopic variation. Samples were taken from five cores from three sites along the Kiamichi River and one sample was taken from a pebble from a locality on the Red River floodplain in Bossier Parish, Louisiana (Figure 8). Sample selection was biased towards sites along the lower Kiamichi River because these sites contained the largest array of cores from which to select samples illustrating variation in color.

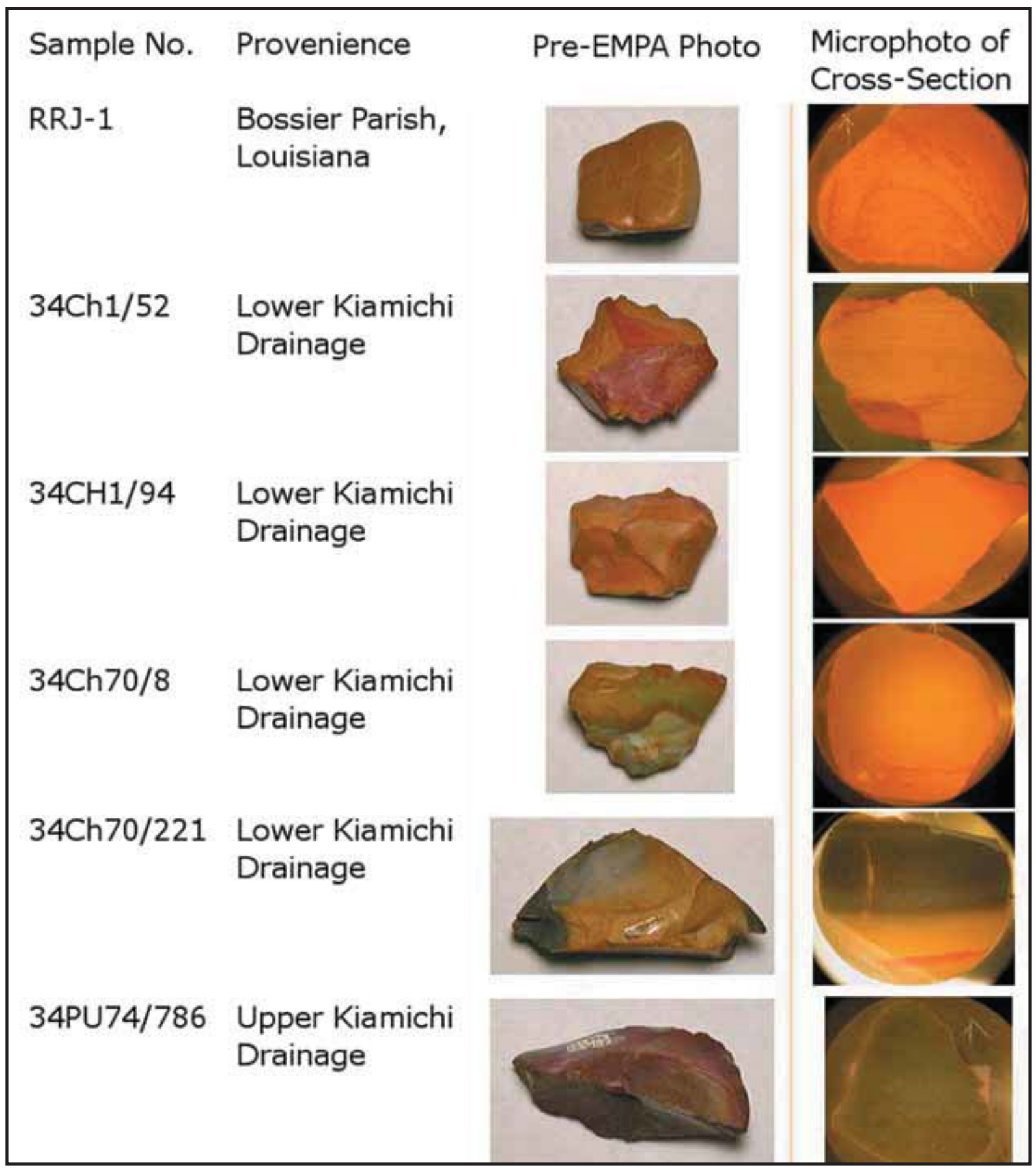

Figure 8. Samples of Red River Jasper used for electron microprobe analysis. The photos on the left were taken before analysis. The photos on the right show a cross-section of each piece embedded in epoxy resin. 
The samples were prepared for analysis as thick sections embedded in epoxy. A microphotograph was taken of each sample to examine structure under relatively low magnification. This was helpful for selecting portions of the sample that cut across macroscopic bands of variation for closer analysis through the acquisition of backscattered electron images and cathodoluminescence (CL) images. In several cases the cross-sectional microphotographs also revealed structural aspects of the cores that were not visible prior to creating a crosssection. The exterior of core 34PU74/766 was entirely red, even where flakes had been removed, so it was expected that the inner material would also be red. In cross-section, however, it became apparent that only the exterior was red, whereas the interior was actually gray with some olive gray bands. This indicates that the artifact must have weathered in situ, following flake removal, highlighting the weathering capability of this material and supporting post-diagenic chemical weathering as the likeliest explanation for variation in color. Cross-sections of the pebble from Louisiana and two of the cores from sites along the Kiamichi (34CH1/52 and 34CH70/221) illustrate the internal banding that seems to be common to this material. These bands were targeted in the microprobe analysis as potential localities of structural or chemical variation.

Backscattered electron imaging (BSEI) and CL were the two primary analytic methods used for this microprobe study (under the direction of Dr. George Morgan at the University of Oklahoma) to acquire structural, mineralogical, and chemical information on a set of materials classified as Red River Jasper based on their macroscopic characteristics.

Two images acquired through BSEI are illustrated here, from samples RRJ-1 and 34PU74/766 (Figure 9). These images are representative of all six samples. Each shows that the samples have a high level of mineralogical homogeneity, with minerals distributed relatively evenly within each sample regardless of macroscopic banding. The dark gray portions of the image represent quartz $\left(\mathrm{SiO}_{2}\right)$, with some larger quartz particles present within the matrix. Most of the white parts of the images represent iron oxides, which give this material its yellow, brown, or red color. The macroscopic lighter and darker yellowish-brown banding present in RRJ-1 is not readily discernable in the BSE image. A slight change in the quantity of iron oxides is detectable between the red and gray zones of 34PU74/766, however. The larger (approximately 23 to $58 \mu \mathrm{m}$ ) white particles in the RRJ-1 BSE image represent minerals common to sedimentary systems, including Iron Aluminum Phosphate and Barium Sulfate. The black portions in each of the BSE images represent holes filled with epoxy, where mineral particles popped out of the sample during polishing.

BSEI demonstrates that Red River Jasper is generally a mineralogically and structurally homogeneous material. Its primary content is quartz, followed by a series of iron oxides. For the most part, the iron oxides are evenly distributed within each sample. Some samples also contain small quantities of other minerals that are common to sedimentary systems. The main source of variation within certain samples is associated with the differential distribution of iron oxides in yellow or red zones vs. gray or black zones. While these macroscopically different zones all contain some amount of iron oxides, the yellow or red zones contain considerably more of these minerals. Iron oxides are also distributed variably between the samples, explaining the overall variation of color. Color variability may also be related to differences in the properties of the iron oxides. Those portions of the samples containing more iron oxides have undergone a greater degree of chemical weathering than those containing fewer iron oxides.

Very little variability in the CL signal was detected within the samples. This was not unexpected as cherts are often unresponsive to CL (Morgan, personal communication 2009). Other archaeologists studying cherts and quartzites have suggested that instrumental neutron activation analysis (INAA), X-ray florescence (XRF), and inductively coupled plasma mass spectrometry (AD- or LA-ICP-MS) are more useful techniques for the detection of trace elements and isotopic signatures (King et al. 1997:796; Malyk-Selivanova et al. 1998; Pitblado et al. 2008). However, these authors and others (Frahm 2007; Luedtke 1992:57-60) have also noted 
that any given chert formation may encompass a large amount of chemical variability. When used for sourcing, trace element analyses require a large number of samples, both archaeological and from the hypothesized formation to gain any sort of statistical validity. This was outside the scope of this study, which instead focused more on the physical structure and distribution of Red River Jasper.

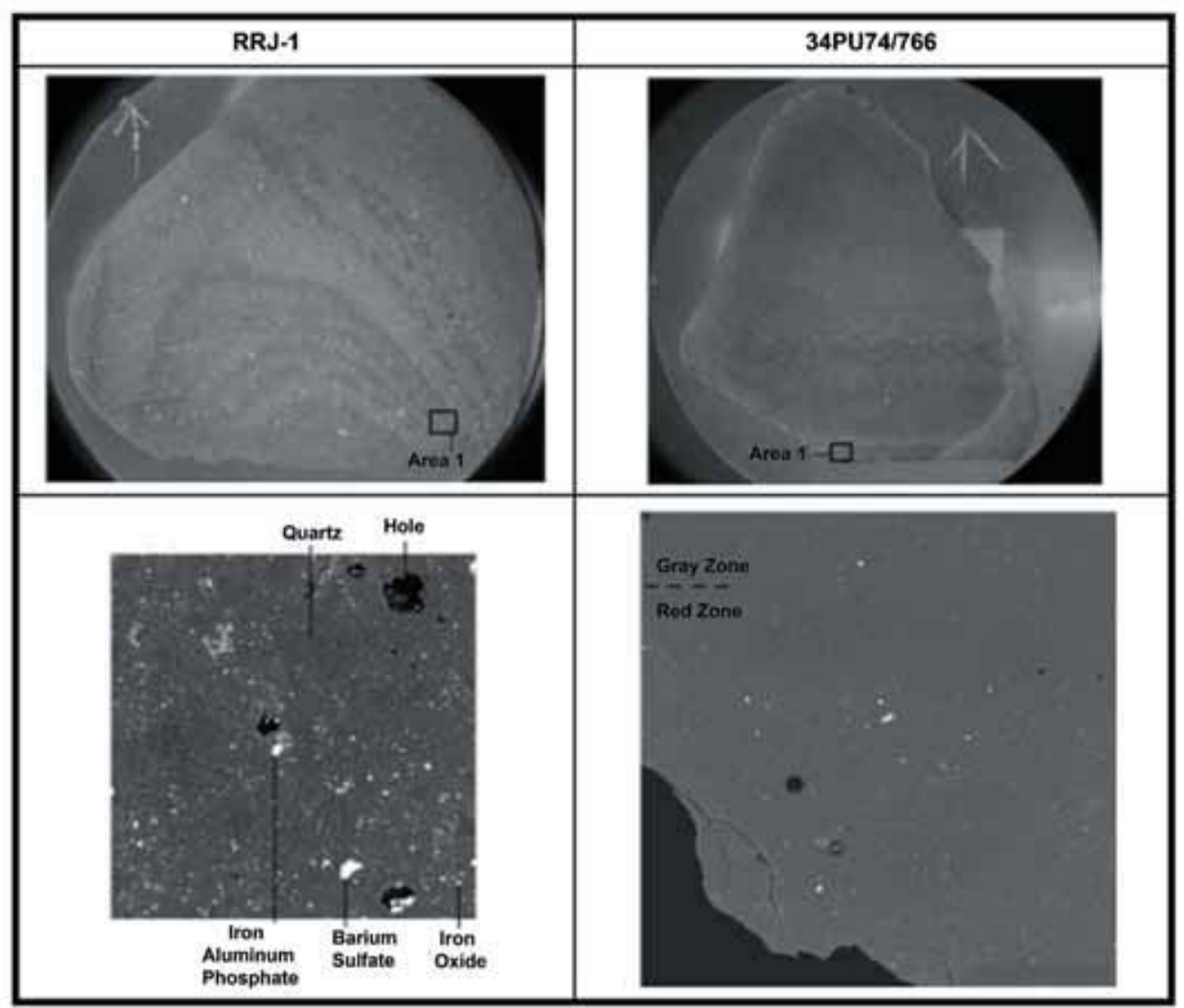

Figure 9. Microphotographs (top) of two samples, RRJ-1 from Louisiana and 34PU74/766 from the upper Kiamichi drainage, showing the location of backscattered electron (BSE) images (bottom). The BSE images illustrate the mineralogy and structure of the material. Both samples are composed primary of quartz with small quantities of iron oxides and other minerals common to sedimentary systems. Little variation is present except for the distribution of iron oxides, which explains macroscopic variation.

\section{Sourcing Red River Jasper: Archaeological Distribution and Geological Sources}

\section{Archaeological Distribution}

In order to investigate the potential source of Red River Jasper, a series of lithic assemblages were examined (Table 3). Based on prior observations, Wyckoff (personal communication 2008) hypothesized that the material was coming out of the Ouachita Mountains of Oklahoma, probably from a formation within the Kiamichi River drainage. The Ouachita Mountains are comprised of deeply folded and faulted ranges generally running east to west situated between the Arkansas Valley to the north and the Gulf Coastal Plain to the south (Banks 1990:33; Hart 1963:11; Johnson 1998:3; Thornbury 1965:279-281). The Ouachita Mountains are approximately $402 \mathrm{~km}(250 \mathrm{mi}$ ) long and average $80 \mathrm{~km}(50 \mathrm{mi})$ in width, ranging from Atoka, Oklahoma to near Little Rock, Arkansas. The rocks of the Ouachitas are all sedimentary, primarily sandstones and shales with smaller amounts of chert, quartzite, and novaculite (Johnson 1998:3). The mountain belts are mostly composed of resistant sandstone and cherts, whereas the valleys formed within the shales. 
Lithic assemblages from eleven sites along the major drainages of the Ouachitas, including the Kiamichi, Little, Glover, and Mountain Fork rivers, were chosen for this study. Twelve additional sites along the Muddy Boggy River, which runs through the western-most extension of the Ouachitas, were inspected. No Red River Jasper was found in these assemblages. One site along the Red River upstream (west) of its confluence with the Kiamichi was also examined, because Red River Jasper was known to occur within the assemblage of that site. Artifacts from these sites range in age from the Archaic to late prehistoric period.

Table 3. Assemblages examined for Red River Jasper. Sites listed geographically by drainage from west to east.

\begin{tabular}{|c|c|c|c|c|c|}
\hline Map \# & Site Name & Site \# & Drainage & $\begin{array}{l}\text { Red River Jasper } \\
\text { Present? }\end{array}$ & Site Reference(s) \\
\hline 1 & James & 34BR11 & Red/Washita & Y & - \\
\hline 2 & George & 34AT105 & Muddy Boggy & $\mathrm{N}$ & McGuff 1980 \\
\hline 3 & Green Snake & 34AT106 & Muddy Boggy & $\mathrm{N}$ & McGuff 1980 \\
\hline 4 & Firecracker & 34AT107 & Muddy Boggy & $\mathrm{N}$ & McGuff 1980 \\
\hline 5 & Velt & 34AT108 & Muddy Boggy & $\mathrm{N}$ & McGuff 1980 \\
\hline 6 & Hurry Up & 34AT109 & Muddy Boggy & $\mathrm{N}$ & McGuff 1980 \\
\hline 7 & Loads & 34AT111 & Muddy Boggy & $\mathrm{N}$ & McGuff 1980 \\
\hline 8 & Pittance & 34AT112 & Muddy Boggy & $\mathrm{N}$ & McGuff 1980 \\
\hline 9 & Funny Feature & 34AT113 & Muddy Boggy & $\mathrm{N}$ & McGuff 1980 \\
\hline 10 & - & 34AT114 & Muddy Boggy & $\mathrm{N}$ & McGuff 1980 \\
\hline 11 & Texas Hole & 34AT115 & Muddy Boggy & $\mathrm{N}$ & McGuff 1980 \\
\hline 12 & Sappho & 34AT116 & Muddy Boggy & $\mathrm{N}$ & McGuff 1980 \\
\hline 13 & Will o the Wisp & 34AT117 & Muddy Boggy & $\mathrm{N}$ & McGuff 1980 \\
\hline 14 & Montgomery & $34 \mathrm{CH} 70$ & Lower Kiamichi & Y & Rohrbaugh 1971, 1972 \\
\hline 15 & Mahaffey & $34 \mathrm{CH} 1$ & Lower Kiamichi & Y & $\begin{array}{l}\text { Rohrbaugh et al. 1971; } \\
\text { Rohrbaugh } 1972\end{array}$ \\
\hline 16 & Natural Lake & 34PU71 & $\begin{array}{l}\text { Upper Kiamichi } \\
\text { (Jackfork Creek) }\end{array}$ & $\mathrm{N}$ & Lintz 1979a \\
\hline 17 & Blessingame & 34PU74 & $\begin{array}{l}\text { Upper Kiamichi } \\
\text { (Buffalo Creek) }\end{array}$ & Y & Lintz 1979b \\
\hline 18 & Arrrowhead Hill & 34PU105 & $\begin{array}{l}\text { Upper Kiamichi } \\
\text { (Buffalo Creek) }\end{array}$ & Y & Vehik 1979 \\
\hline 19 & Buffalo Bend & 34PU111 & $\begin{array}{l}\text { Upper Kiamichi } \\
\text { (Buffalo Creek) }\end{array}$ & Y & Flynn et al. 1979 \\
\hline 20 & Bell & $34 \mathrm{MC} 76$ & Little & Y & Wyckoff 1968a \\
\hline 21 & A.W. Davis & 34MC6 & Little/Glover & Y & Wilson 1962 \\
\hline 22 & $\begin{array}{l}\text { Pine Creek Mound } \\
\text { Group }\end{array}$ & $34 \mathrm{MC} 146$ & Glover & Y & Gettys 1975 \\
\hline 23 & Bill Hughes & 34MC21 & Mountain Fork & $\mathrm{N}$ & Wyckoff $1968 b$ \\
\hline 24 & Biggham Creek & $34 \mathrm{MC} 105$ & Mountain Fork & Y & Wyckoff 1965 \\
\hline
\end{tabular}

Within each assemblage, all cores, bifaces, and bifacial tools were examined for Red River Jasper. Attributes and variables were recorded for all artifacts made from this material. These included reduction stage, any diagnostic attributes, whether or not cortex was present, maximum length, maximum thickness, texture, cortex color, matrix color, inclusions, and notes on color transitions within the material (mottled, banded, transitional, or red tips on finished tools). 
Of the assemblages along the drainages coming out of the Ouachita Mountains, nine contained cores, bifaces, and/or bifacial tools made of Red River Jasper. The relative proportion of cores, early stage bifaces, and artifacts with cortex within each Red River Jasper assemblage was determined to identify what stages of the reduction process were practiced at different sites (Table 4). A higher proportion of cores, early stage bifaces, and artifacts with cortex demonstrates that the material went through the initial stages of reduction at that site. This suggests that the material was acquired locally. A lower proportion of cores, conversely, implies that more of the material was initially worked elsewhere and was brought to the site in the form of late stage bifaces and finished tools.

Table 4. Sites with Red River Jasper artifacts. Total number of artifacts and number and percent of cores, early stage bifaces, and artifacts with cortex within each assemblage. Sites listed geographically by drainage from west to east.

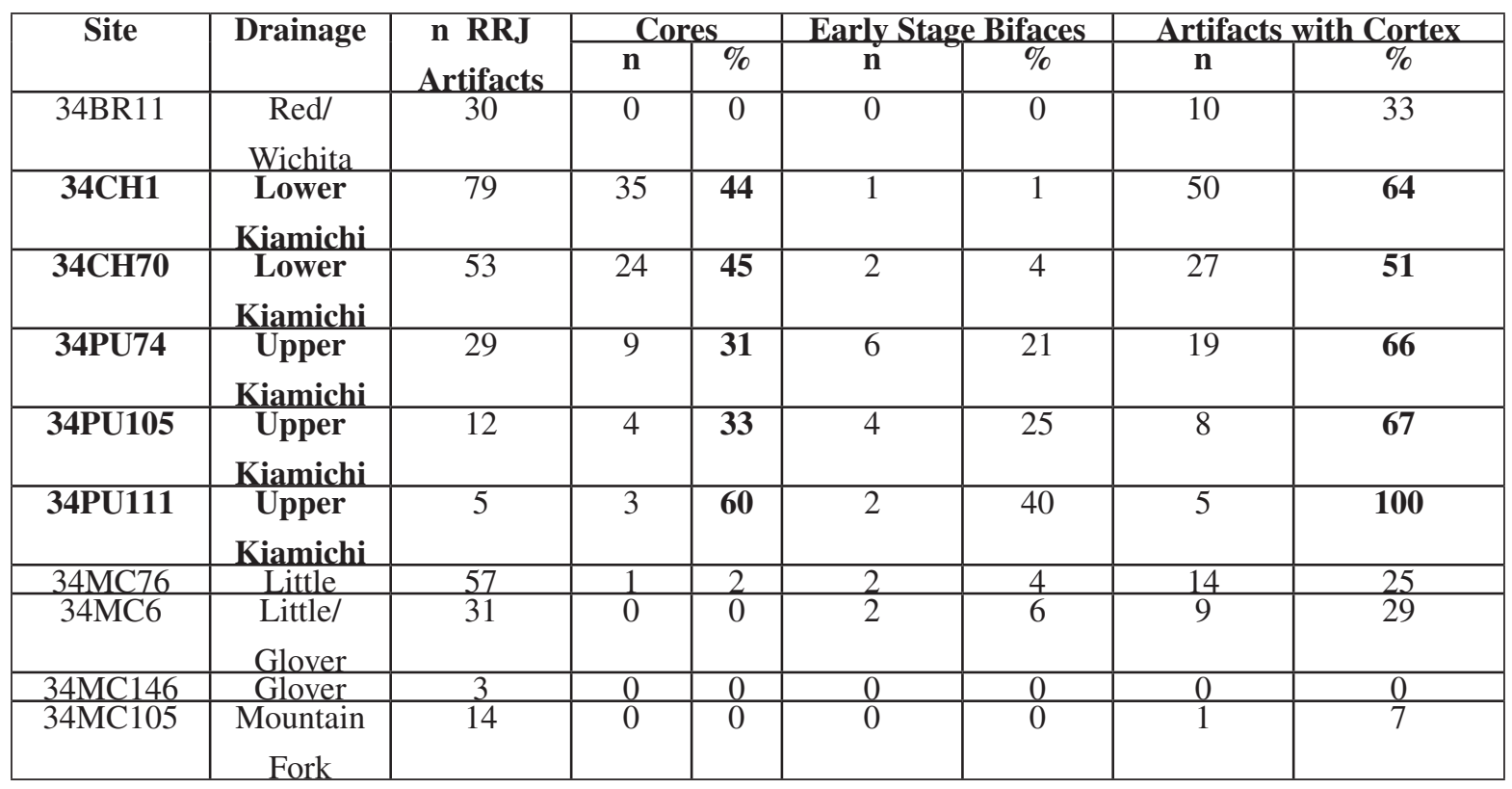

By far the highest percentages of Red River Jasper cores occur within the assemblages of sites along the upper and lower reaches of the Kiamichi River (Figure 10). This strongly suggests that people living at these sites acquired this material locally, whereas the people living in distant drainages transported it in an already reduced form. Sites with the highest proportions of early stage bifaces include all of those along the upper Kiamichi. Sites along the lower Kiamichi, however, have a much lower proportion of early stage bifaces, equal or less than the proportion of early stage bifaces at sites along the Little River. It is possible that fewer early stage bifaces are present at the sites along the lower Kiamichi because the material was traded out in this form. This might explain the presence of a relatively equal proportion of early stage bifaces at the Little River sites. People living along the Little River, which is the next major drainage east of the Kiamichi, did not have far to travel to reach the lower Kiamichi sites, reducing the potential difficulty of carrying the material from one river to the next. Red River Jasper cores were small to begin with, though, and carrying bifaces in the early stages of the reduction process may not have imposed any particular difficulty. One of the sites under consideration along the lower Kiamichi (34CH1) and both sites along the Little River (34MC76 and 34MC6) included late prehistoric Caddo components. The Caddo people living at these sites may have been connected to each other within a trade network. It is also possible that the residents along the Little River traveled to the Kiamichi River independently, acquired Red River Jasper cobbles purposefully or circumstantially, partially reduced them, and taken them to their sites for further reduction. 
The proportions of artifacts with cortex in the Red River Jasper assemblages represent a wider range of variation. Nonetheless, sites along the Kiamichi still exhibit the highest proportions, supporting the idea that the material originates within that drainage.
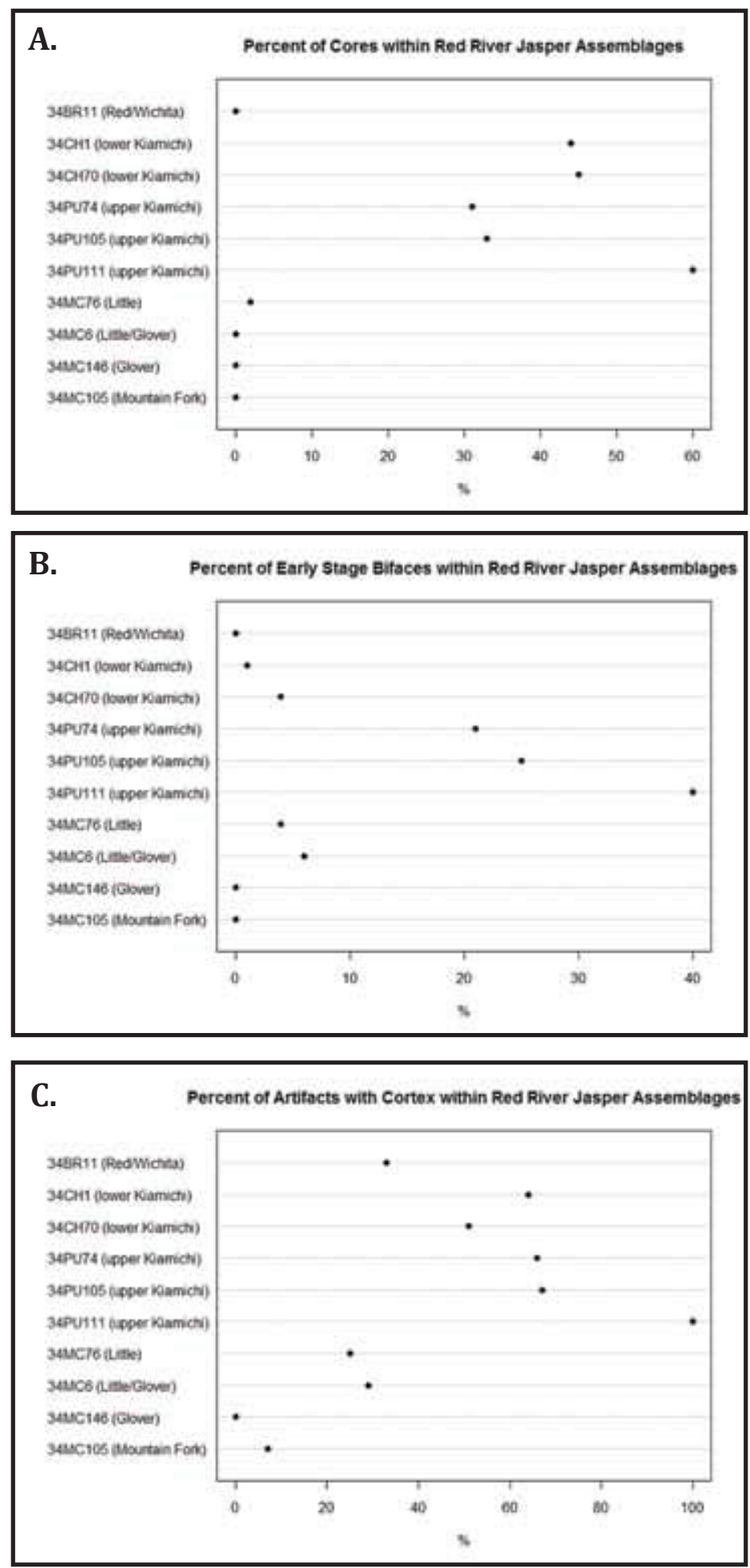

Figure 10. Proportion of cores, early stage bifaces, and artifacts with cortex present within assemblages of Red River Jasper. The assemblages with the highest percentages of cores, early stage bifaces, and artifacts with cortex are all from the Kiamichi drainage, indicating that these people had the most immediate access to the raw material. This supports the hypothesis that the Kiamichi River was a primary source within the Ouachita Mountains for Red River Jasper. 


\section{Stream Survey and Geological Origins}

The proportions of cores, early stage bifaces, and artifacts with cortex from these assemblages all point to the Kiamichi River as the most likely source for Red River Jasper gravels. Based on the high proportion of cores and early stage bifaces at sites along the upper reaches of the Kiamichi, this portion of the drainage is the most likely location of the formation(s) from which these gravels are eroding. Narrowing down the potential location (or locations) and the composition of this formation(s) involved two approaches. First, a survey was conducted at locations sequentially farther upstream along the Kiamichi to determine how far upstream the Red River Jasper gravels occur. This aided in the identification of streams feeding the Kiamichi that may cut across the contributing formation(s). Second, potential chert-bearing formations within this range were examined. Through consultation with the Oklahoma Geological Survey, the Johns Valley Formation was identified as the most likely source material for Red River Jasper. Outcrops of the Johns Valley Formation are present in the Winding Stair Range of the Ouachita Mountains north of the Kiamichi River. Together, the archaeological, survey-based, and geological evidence point to a limited number of potential outcrops of the Johns Valley Formation cross-cut by streams draining into the Kiamichi River from which Red River Jasper may be originating (Figure 11).

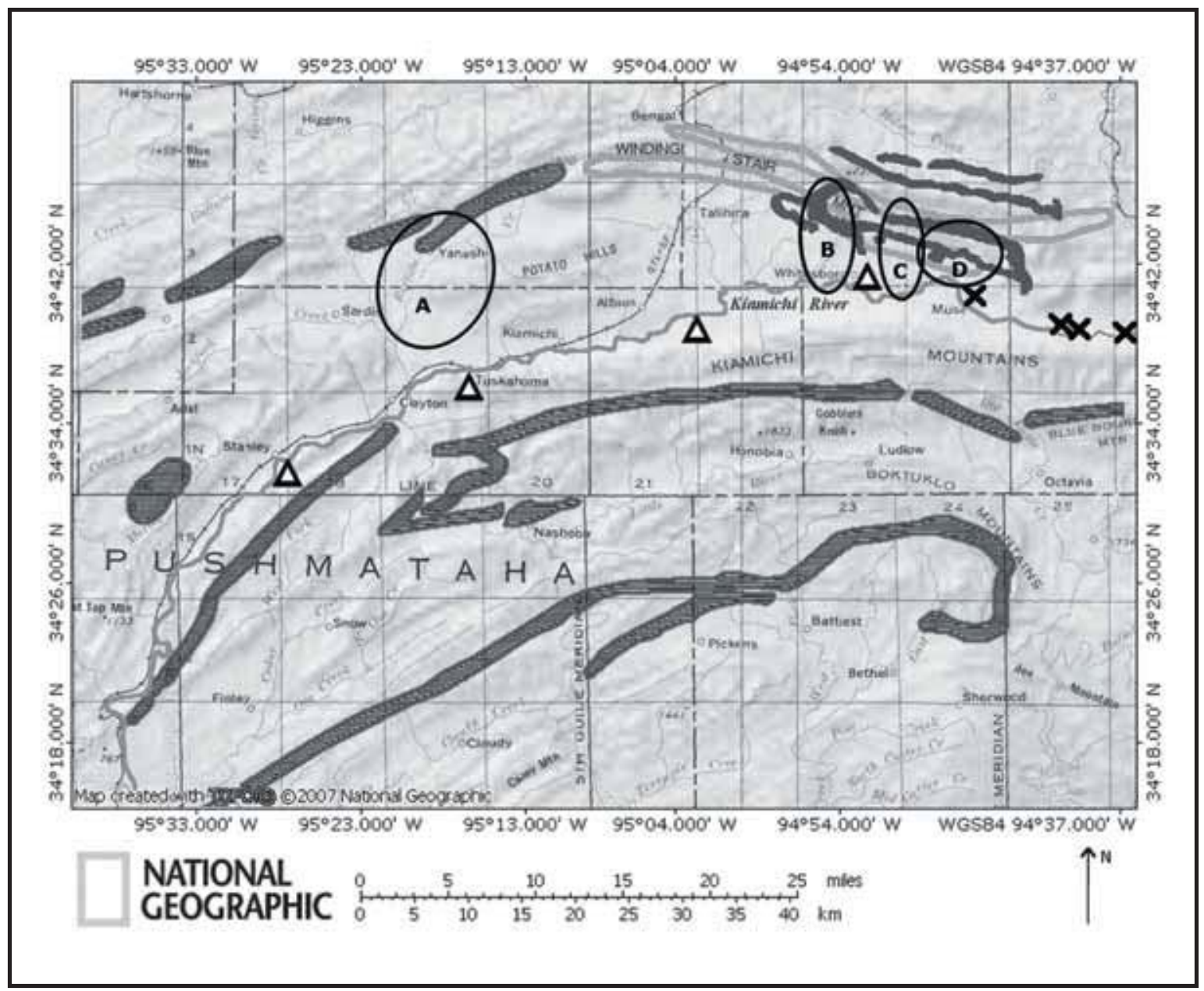

Figure 11. Distribution of the Johns Valley Formation in the Ouachita Mountains, Oklahoma, in relation to a survey of gravels along the banks of the Kiamichi River for Red River Jasper. The shaded areas indicate outcrops of the Johns Valley Formation (dark shaded areas adapted from Banks 1990:Figure 1.20 and light shaded areas adapted from Hart 1963:Plate I). $\Delta$ indicates the presence of Red River Jasper during the gravel survey along the Kiamichi River; X indicates its absence. Localities A through D indicate potential sources for Red River Jasper or for its antecedent, outcrops of iron-rich John's Valley chert. Base map courtesy of National Geographic TOPO! Software. 
Most major rivers draining the Ouachitas flow south where they join the eastward-flowing Little River, which eventually joins the Red River in Arkansas. The Kiamichi River flows westward-paralleling the mountains-until it turns south near Clayton and eventually joins the Red River. The portion of the Kiamichi River under discussion is situated in a broad alluvial valley in the central part of the Ouachita Mountains known as the Fourche-Kiamichi Belt (Thornbury 1965:283). This part of the river valley is bounded by the Potato Hills and the Winding Stair Range to the north and the Kiamichi Mountains to the south.

Based on the physical characteristics of Red River Jasper, its known distribution, and the geological history of the region, Neil Sunerson (personal communication 2008) of the Oklahoma Geological Survey has suggested that it comes from the Johns Valley Formation. The Johns Valley Formation was first named by Ulrich (1927:21-22) and chert in the formation has been discussed by Banks (1984:91, 1990:46) and Hart (1963:3040). This formation is composed primarily of shale but also contains exotic chert cobbles and boulders. Some debate exists over the origin of these chert clasts. Hart (1963:36-40) argued that they became embedded in the shale following a violent faulting episode, in which the boulders were transported through underwater turbidity flows and gravity slides down the muddy northern slope of the Ouachita trough. This may have occurred sometime during the Upper Mississippian to Lower Pennsylvanian period (328.3 \pm 1.6 to $311.7 \pm 1.1$ mya) of the Paleozoic era (Gradstein et al. 2004; Hart 1963:40; Ogg et al. 2008).

The type location for the Johns Valley Formation is located in Johns Valley, northwest of the Kiamichi River. Other outcrops of the Johns Valley Formation occur in linear bands along the Winding Stair Range and Kiamichi Mountains, respectively north and south of the Kiamichi River in the section of interest (Banks 1990:Fig. 1.20; Miser 1959:Fig. 3). Because the streams that enter the Kiamichi River from the south are considerably smaller than those from the north, it is more likely that the source for Red River Jasper lies in the linear outcrop to the north of the river.

A detailed geological map of the Winding Stair Range near the surveyed portion of the Kiamichi River is presented by Hart (1963). All of the major streams that feed the Kiamichi from the Winding Stair Range in this area cut across a Johns Valley Formation outcrop. This outcrop pinches out and ends just past the last place where Red River Jasper was found along the Kiamichi, providing further support for a Red River Jasper origin within this range. A broader-scale map of chert-bearing formations by Banks (1990:Fig. 1.20) suggests several other potential localities for Johns Valley source material within the study area. Further work would be required to determine whether Red River Jasper is coming from one or multiple sources, but at least one source must include the outcrop cross-cut by streams between the towns of Whitesboro and Muse in the Kiamichi Valley.

The exotic boulders of the Johns Valley Formation include Arkansas Novaculite along with Woodford, Pinetop, and Big Fork cherts and quartzites (Banks 1984:91). Of these, Woodford Chert most resembles the less-weathered gray to black specimens of the Red River Jasper gravels. Woodford Chert that is not embedded within the Johns Valley Formation outcrops near belts of Johns Valley Shale at isolated localities along the crest of the Winding Stair Range (Banks 1990:40). Like Red River Jasper, the material is opaque, and Banks (1990:41) has noted that iron pyrite and iron-oxide staining is common along fractures. The chert from which Red River Jasper originates could be a variant of Woodford Chert or it could be an as-of-yet unidentified chert, in either case situated within the Johns Valley Shale. This chert was apparently particularly susceptible to chemical weathering, perhaps because it was more porous than other cherts or lengthy exposure to water in its small tabular form. As it entered the Kiamichi drainage, it gradually transformed into Red River Jasper, in some cases changing color throughout by the time it was acquired and used to make tools. 
Banks (1995:13) mentioned a green chert that occurs in fractured beds in the Potato Hills and at Black Knob Ridge east of Atoka. He traced gravels of this material in the Kiamichi River south of the Potato Hills and found that it weathered to shades of brown and yellow. It is possible that this represents another variety of what has been called Red River Jasper, one with a different parent formation. Of the cores from the archaeological assemblages, a few have portions that were light olive brown. It is possible that Red River Jasper, particularly once it works its way downstream, is actually composed of multiple materials that chemically weather to a similar appearance.

\section{Conclusion}

Archaeologists base many of their interpretations on lithic artifacts, the best-preserved and most abundant artifacts at sites spanning most of human history. Because of this, understanding the character and natural distribution of lithic raw materials is essential for interpreting the archaeological record (Wyckoff 2006). Whereas many raw materials on the Southern Plains are well-documented, this paper represents the first serious report of the characteristics and distribution of Red River Jasper. It is evident that many of these tabular brown chert gravels that occur in the Red River drainage come out of the Ouachita Mountains via the Kiamichi River. The most likely source for these gravels is the Johns Valley Formation, which is cross-cut by a number of feeder streams to the Kiamichi within the Winding Stair Range. As the gravels erode from the Johns Valley Formation, they undergo chemical weathering that gives them their yellow-brown to red colors. Future survey along Buffalo Creek, Rock Creek, and other streams draining the Winding Stair Range may narrow down the location of the source or sources of the gravels within the Johns Valley Formation. It is possible that other sources for materials classified as Red River Jasper may also exist.

Knowing the natural range of Red River Jasper helps us to understand which people acquired the material locally and who had to travel or trade in order to obtain it. The identification of Red River Jasper at sites outside of its natural range, though, can be complicated by its sometimes macroscopic similarity to other local gravels, such as those from the Antlers Formation. While these gravels are easily distinguishable in core form, they are more difficult to differentiate further on in the reduction sequence. Microscopic and trace-element analyses comparing some of these cherts may help archaeologists to more accurately distinguish between them, but too much variation may exist within each material to tell them apart. However, archaeologists can productively focus on the macroscopic suites of attributes that differentiate these cherts and on identifying Red River Jasper cores, which are easily distinguishable. Understanding the characteristics and natural range of Red River Jasper may help archaeologists in understanding the potential processes underlying its cultural distribution.

\section{Acknowledgements}

First and foremost, all of my thanks to Don Wyckoff for encouraging me to embark on this project, for making me appreciate the importance of understanding lithic materials, and for funding my travels through southeastern Oklahoma. Thank you to the Sam Noble Oklahoma Museum of Natural History, George Morgan at the University of Oklahoma electron microprobe lab, Neil Sunerson at the Oklahoma Geological Survey, Jeffrey Girard at Northwestern State University of Louisiana, and the United States Army Corps of Engineers Tulsa District, in particular Michelle Horn and Ken Shingleton. A big thanks to my husband, Tim, for traversing the Kiamichi with me in search of gravels and carting chert through the Ouachitas. Finally, my thanks to my reviewers, Charlie Cobb, and George Avery. 


\section{References Cited}

Banks, Larry D.

1984 Lithic Resources and Quarries. In Prehistory of Oklahoma, edited by R. E. Bell, pp. 65-95. Academic Press, Orlando.

1990 From Mountain Peaks to Alligator Stomachs: a Review of Lithic Sources in the Trans-Mississippian South, the Southern Plains, and Adjacent Southwest. Oklahoma Anthropological Society, Memoir 4. Norman.

1995 Appendix B. Classification and Identification of Lithic Artifacts and their Geologic Sources of Origin for Texas Archeological Site 41BW422, Bowie County, Texas. In Archaic Lifeways in the Northern Part of the West Gulf Coastal Plain: results of Excavations at Site 41BW422, Bowie County Texas, by Gordon C. Tucker Jr. Prepared for Texas State Department of Highways and Public Transportation. Austin, Texas.

Bates, Robert L. and Julia A. Jackson (editors)

1980 Glossary of Geology. $2^{\text {rd }}$ ed. American Geological Institute, Falls Church, Virginia.

Flynn, Peggy, Marjorie Hammett Earman, and Rain Vehik

1979 Test Excavations at the Buffalo Bend Site (34Pu-111). In The Prehistory of the Proposed Clayton Lake Area, Southeast Oklahoma: Phase I Investigations, edited by Rain Vehik and Jerry R. Galm, pp. 452-487. Archaeological Research and Management Center, Research Series 6. University of Oklahoma, Norman.

Frahm, Ellery

2007 Electron Microprobe Analysis in Archaeology. Example: Examining the Microstructure of Flint and Chert. Electronic document, http://web.mac.com/elleryfrahm/iWeb/Microprobe/ Electron\%20Microprbe\%20Analysis\%20in\%20Archaeology/F75D2AC4-3FB1-4F39-A941DDB9B523A2EF.html, accessed April 24, 2009.

Gettys, Marshall

1975 Preliminary Report on Archaeological Investigations at Lukfata Reservoir, Southeastern Oklahoma. Oklahoma River Basin Survey Project, General Survey Report No. 14. University of Oklahoma, Norman.

Gordon, S. and R.I. Dorn

2004 Rind, Weathering. In Encyclopedia of Geomorphology, edited by A.S. Goudie, pp. 853-855. Routledge, London.

Gradstein, F. M., J. G. Ogg, A. G. Smith, et al.

2004 A Geologic Time Scale 2004. Cambridge University Press.

Hart, Orville Dorwin

1963 Geology of Eastern Winding Stair Range Le Flore County. Oklahoma Geological Survey, Bulletin 103. University of Oklahoma, Norman.

Hurst, V. J. and A. R. Kelly

1961 Patination of cultural flints. Science 134:251-256.

Jennings, Thomas A.

2006 San Patrice Technology and Mobility Across the Plains-Woodland Border. Master's Thesis, submitted to the University of Oklahoma. 


\section{References Cited (cont.)}

Johnson, Kenneth S.

1998 Mountains, Streams, and Lakes of Oklahoma. Oklahoma Geological Survey, Information Series \#1. Reprinted from Oklahoma Geology Notes (1993), vol. 53, no. 5, pp. 180-188.

King, Adam, James W. Hatch, and Barry E. Scheetz

1997 The Chemical Composition of Jasper Artefacts from New England and the Middle Atlantic: Implications for the Prehistoric Exchange of "Pennsylvania Jasper". Journal of Archaeological Science 24:793-812.

Lintz, Christopher

1979a The Natural Lake Site (34Pu-71). In The Prehistory of the Proposed Clayton Lake Area, Southeast Oklahoma: Phase I Investigations, edited by Rain Vehik and Jerry R. Galm, pp. 125-168. Archaeological Research and Management Center, Research Series 6. University of Oklahoma, Norman.

1979b The Blessingame Site (34Pu-74). In The Prehistory of the Proposed Clayton Lake Area, Southeast Oklahoma: Phase IInvestigations, edited by Rain Vehik and Jerry R. Galm, pp. 244-362. Archaeological Research and Management Center, Research Series 6. University of Oklahoma, Norman.

Lovering, T. G.

1972 Jasperoid in the United States: its characteristics, origin, and economic significance. United States Geological Society Professional Paper 710:1-164.

Luedtke, Barbara A.

1992 An Archaeologist's Guide to Chert and Flint. Archaeological Research Tool 7. Institute of Archaeology, University of California, Los Angeles.

Malyk-Selivanova, Natalia, Gail M. Ashley, Robert Gal, Michael D. Glascock, and Hector Neff

1998 Geological-Geochemical Approach to "Sourcing" of Prehistoric Chert Artifacts, Northwestern Alaska. Geoarchaeology 13(7):673-708.

McGuff, Paul

1980 Cultural Resource Survey and Testing at the McGee Creek Project, Oklahoma. Prepared for the United States Department of the Interior Bureau of Reclamation, Southwest Region, Amarillo, Texas. Environmental Assessments, Inc., Pauls Valley, Oklahoma.

Miser, Hugh D.

1959 Structure and Vein Quartz of the Ouachita Mountains of Oklahoma and Arkansas. In The Geology of the Ouachita Mountains: A Symposium, edited by Lewis M. Cline, William J. Hilseweck, and Dan E. Feray, pp. 30-43. Dallas Geological Society and Ardmore Geological Society, Dallas.

Ogg, J. G., G. Ogg, and F. M. Gradstein

2008 The Concise Geologic Time Scale.

Pitblado, Bonnie L., Carol Dehler, Hector Neff, and Stephen T. Nelson

2008 Pilot Study Experiments Sourcing Quartzite, Gunnison Basin, Colorado. Geoarchaeology 23(6):742778. 


\section{References Cited (cont.)}

Rohrbaugh, Charles L.

1972 Hugo Reservoir II: A Discussion of the Development of the Archaic Cultures in Hugo Reservoir into the Pre-Formative and Formative Tradition and Including the Descriptions of Three Archaic Sites Dug During the 1970 Field Season: Ch-89, The McKensie Site; Pu-58, The Hill Site, and Ch-113A, The Pat Boyd Place, Area A. Oklahoma River Basin Survey, Archaeological Site Report 23. University of Oklahoma Research Institute, Norman.

Rohrbaugh, Charles L., Robert J. Burton, Susan Sasse Burton, and Lura Joseph Rosewitz

1971 Hugo Reservoir 1: The Description of the Archaeological Sites Excavated Ruing the 1970 Field Season Including Ch-1, Ch-43, Ch-70, Ch-75, Pu-82 and Ch-90. Oklahoma River Basin Survey, Archaeological Site Report 22. University of Oklahoma Research Institute, Norman.

Thornbury, William D.

1965 Regional Geomorphology of the United States. John Wiley \& Sons, New York.

Ulrich, E. O.

1927 Fossiliferous boulders in the Ouachita "Caney" shale and the age of the shale containing them. Oklahoma Geological Survey Bulletin 45. Norman.

University of Oklahoma

2009 Electron Microprobe Laboratory. Electronic document, http://research.ou.edu/microprobe/ OUEMPLhome.asp, accessed April 24, 2009.

Vehik, Rain

1979 Phase I Excavations at the Arrowhead Hill Site (34Pu-105). In The Prehistory of the Proposed Clayton Lake Area, Southeast Oklahoma: Phase I Investigations, edited by Rain Vehik and Jerry R. Galm, pp. 394-451. Archaeological Research and Management Center, Research Series 6. University of Oklahoma, Norman.

Webb, Clarence H., Joel L. Shiner, and E. Wayne Roberts

1971 The John Pearce Site (16CD56): A San Patrice Site in Caddo Parish, Louisiana. Bulletin of the Texas Archaeological Society 42:1-49.

Wilson, Rex

1962 The A.W. Davis Site, Mc-6, of McCurtain County, Oklahoma. Bulletin of the Oklahoma Anthropological Society 10:103-152.

Wyckoff, Don G.

1965 Biggham Creek Site, McCurtain County, Oklahoma. Oklahoma River Basin Survey, General Survey Report 3. University of Oklahoma, Norman.

1968a The Bell and Gregory Sites: Archaeological Chronicles of Prehistory in the Pine Creek Reservoir Area, Southeast Oklahoma. Oklahoma River Basin Survey, Archaeological Site Report 11. University of Oklahoma, Norman.

1968b The Beaver Site and Archaeology of the Broken Bow Reservoir Area, McCurtain County, Oklahoma. Oklahoma River Basin Survey, Archaeological Site Report 9. University of Oklahoma, Norman.

2006 Recent Lithic Technological Studies on the Southern Plains and Adjacent Regions Part I: Identifying and Sourcing Raw Materials. Lithic Technology 30(2):89-106. 